\title{
DESIGN AND FABRICATION OF A MEDIUM SIZE UAV WITH SMART LOCK- SYSTEM FOR WINGS
}

\author{
KRISHN DAS PATEL ${ }^{1}$, S. SMRUTHI ${ }^{2}$, MAUSAM MALLA ${ }^{3}$, M. UDAYA KUMAR ${ }^{4}$ \& SUNNY IZATE $^{5}$ \\ ${ }^{I}$ M. Tech in Aeronautical Engineering, Vel Tech Rangarajan Dr. Sagunthala R\&D Institute of Science and TechnologyAvadi, \\ Chennai, Tamil Nadu, India \\ ${ }^{2}$ Students, Department of Aeronautical Engineering, Vel Tech Rangarajan Dr. Sagunthala $R \&$ D Institute of Science and \\ Technology, Avadi, Chennai, Tamil Nadu, India
}

\begin{abstract}
This paper summarizes the entry of undergraduate students' team for a competition. The team was formed to design, build, test, and fly an Unmanned Aerial Vehicle while keeping in mind to ease the manufacturing and assembly processes capable of lifting heavy loads. The configuration of the aircraft was chosen based on low power to weight ratio and design constraints. To ensure the required aerodynamic forces are met and to distribute the landing impact loads better through the airframe, the CATIA V5, Airfoil section, and structural integrity of landing gear was analyzed using ANSYS 16.2 software. To reduce the unnecessary weight, the structure of the wing and fuselage section was examined. A smart locking system was designed and integrated with the structure to ease the assembly process and to ensure safe attachment of the wing to the fuselage.
\end{abstract}

KEYWORDS: Smart Locking System, Heavy Loads, Airfoil \& Landing Gear

Received: Jun 08, 2020; Accepted: Jun 28, 2020; Published: Sep 03, 2020; Paper Id.: IJMPERDJUN20201045

\section{INTRODUCTION}

An Unmanned Ariel Vehicle (UAV), commonly known as a drone is an aircraft without a human pilot aboard. These aircraft are broadly classified into three categories, namely: Fixed-wing, Rotary wing, and flapping wing UAVs. They are also classified based on size, range, and endurance.Under the fixed-wing category, we have Micro, Mini, Medium, and Large UAVs; Close-range UAVs, Short-range UAVs, Mid-range UAVs and Endurance UAVs; MALE and HALE [1]. UAVs have wide-ranged applications in the industrial, public, and military sectors. Mapping and surveying, inspection and monitoring, aerial imaging, precision agriculture are some of the most important applications.

Traditionally wings are attached to the fuselage in the following three ways:

- $\quad$ Spliced Shear Plates

- Tension Bolts

- $\quad$ Lug Fittings

Though these methods have proved to be sturdy and efficient, we have devised a smart lock system capable of not only safely securing the wing to the fuselage but also enabling speedy assembly and dismantling along with easing the manufacturing process. 
The goal of this team was to design twin-boom tail aircraft that will remain light and still be able to lift a heavy payload. Boom tails are used when an aircraft's fuselage does not extend entirely back to the horizontal stabilizer. It is characterized by two longitudinal booms fixed to its main wing on either side of its centerline. The types of boom tail include, but are not limited to boom-tail, high boom-tail, and inverted v-boom tail.

The advantages of a boom tail are:

- They provide the opportunity to include a very large, robust elevator relative to a single-tailed aircraft, which provides very good control at normal speed.

- They can also stiffen/brace the wing structure in general, and distribute the load more gently.

- The design of twin-boom in an aircraft allows the fuselage to be made very compact and so lighter.

\section{LITERATURE STUDY}

\subsection{Product Study}

Table 1: Product literature study

\begin{tabular}{|l|c|c|c|c|c|c|c|c|}
\hline \multicolumn{1}{|c|}{ Model } & Length & $\begin{array}{c}\text { Wing } \\
\text { Span }\end{array}$ & Mtow & Payload & $\begin{array}{c}\text { Cruise } \\
\text { Speed }\end{array}$ & Range & $\begin{array}{c}\text { Endu- } \\
\text {-Rance }\end{array}$ & $\begin{array}{c}\text { Payload } \\
\text { Ratio }\end{array}$ \\
\hline DVF 2000 & $1.2 \mathrm{~m}$ & $3 \mathrm{~m}$ & $10 \mathrm{~kg}$ & $1.1 \mathrm{Kg}$ & $61.2-97.2 \mathrm{~km} / \mathrm{hr}$ & $5 \mathrm{~km}$ & - & 0.11 \\
\hline Eagle eye & $3.02 \mathrm{~m}$ & $4 \mathrm{~m}$ & $35 \mathrm{~kg}$ & - & $50 \mathrm{~km} / \mathrm{hr}$ & - & $2 \mathrm{hrs}$ & 0.57 \\
\hline Mini Mugin & $2.05 \mathrm{~m}$ & $2.6 \mathrm{~m}$ & $15 \mathrm{~kg}$ & $4 \mathrm{~kg}$ & $120 \mathrm{~km} / \mathrm{hr}$ & - & $2 \mathrm{hrs}$ & 0.26 \\
\hline Mugin Plus & $2.53 \mathrm{~m}$ & $4.5 \mathrm{~m}$ & $28 \mathrm{~kg}$ & $8 \mathrm{~kg}$ & $45-120 \mathrm{~km} / \mathrm{hr}$ & $10 \mathrm{~km}$ & $2 \mathrm{hrs}$ & 0.28 \\
\hline MFD Nimbus & $1.3 \mathrm{~m}$ & $1.8 \mathrm{~m}$ & $5.5 \mathrm{~kg}$ & $1.5 \mathrm{Kg}$ & $140 \mathrm{~km} / \mathrm{hr}$ & - & - & 0.27 \\
\hline Eagle Hero & $1.61 \mathrm{~m}$ & $3.5 \mathrm{~m}$ & $16 \mathrm{~kg}$ & $7.5 \mathrm{~kg}$ & $86 \mathrm{~km} / \mathrm{hr}$ & - & $6.5 \mathrm{hrs}$ & 0.46 \\
\hline Albatross & $0.74 \mathrm{~m}$ & $3 \mathrm{~m}$ & $10 \mathrm{~kg}$ & $4.4 \mathrm{~kg}$ & $60-72 \mathrm{~km} / \mathrm{hr}$ & - & $4 \mathrm{hrs}$ & 0.44 \\
\hline Sky Hunter & $1.4 \mathrm{~m}$ & $1.8 \mathrm{~m}$ & $3.5 \mathrm{~kg}$ & - & - & $5 \mathrm{~km}$ & $2 \mathrm{hr}$ & - \\
\hline Penguin B & $2.27 \mathrm{~m}$ & $3.3 \mathrm{~m}$ & $21.5 \mathrm{~kg}$ & $10 \mathrm{~kg}$ & $79.2 \mathrm{~km} / \mathrm{hr}$ & - & $20 \mathrm{hrs}$ & 0.46 \\
\hline RQ-2 Pioneer & $1.4 \mathrm{~m}$ & $3.5 \mathrm{~m}$ & $10 \mathrm{~kg}$ & - & $72 \mathrm{~km} / \mathrm{hr}$ & $5 \mathrm{~km}$ & - & - \\
\hline
\end{tabular}

Weight estimation of UAVs requires collecting data from existing UAVs, which are similar in characteristics, mission plan, and takeoff weight and payload capacity. A comprehensive study of 10 existing products was carried out, a few of which are mentioned below. (2-7)

\subsection{Graphical Representation of Product Data}

Taking into consideration the data required for weight estimation and design calculation, graphs were plotted between the important parameters of the existing products. After analyzing the obtained graphs, the desired values were estimated from the most clustered area of the graph. 

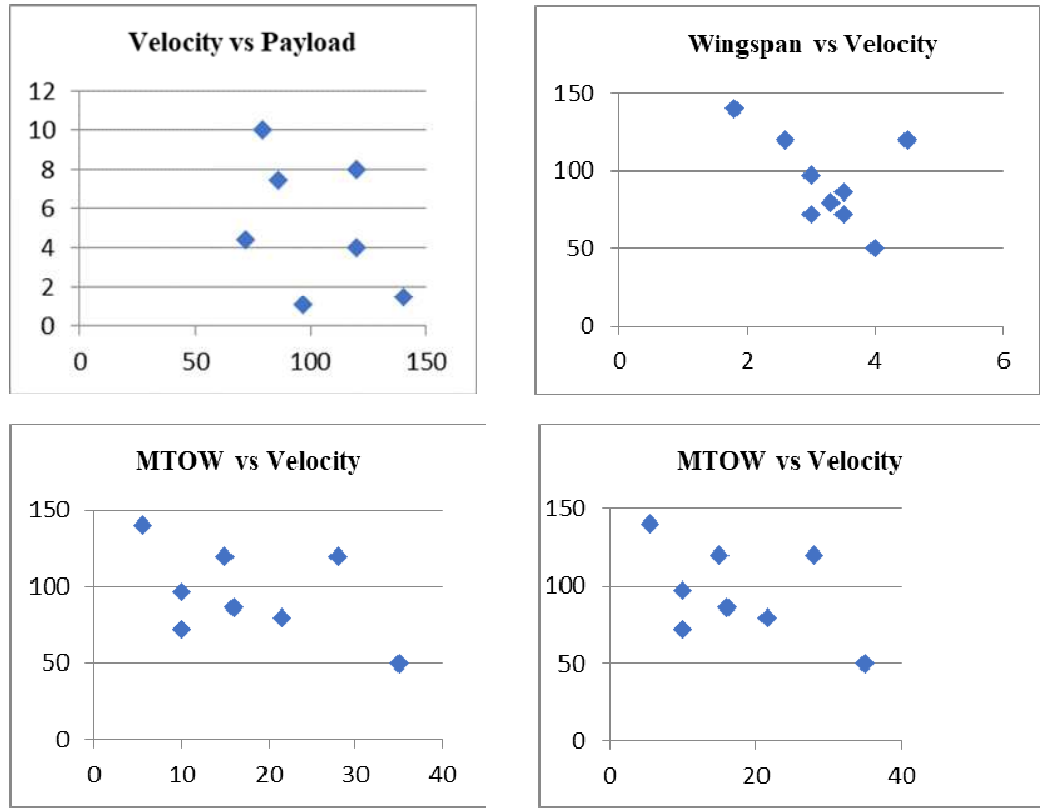

Figure 1: Graphical Representation of Product Data.

\section{METHODOLOGY}

This section describes the methodology adapted to the development of the UAV. The philosophy of this team throughout the design process has centered on developing sound fundamental concepts to satisfy competition requirements. After a satisfactory output, the final model is fabricated and tested. Required changes are made and the model is finalized.

\subsection{Flowchart}

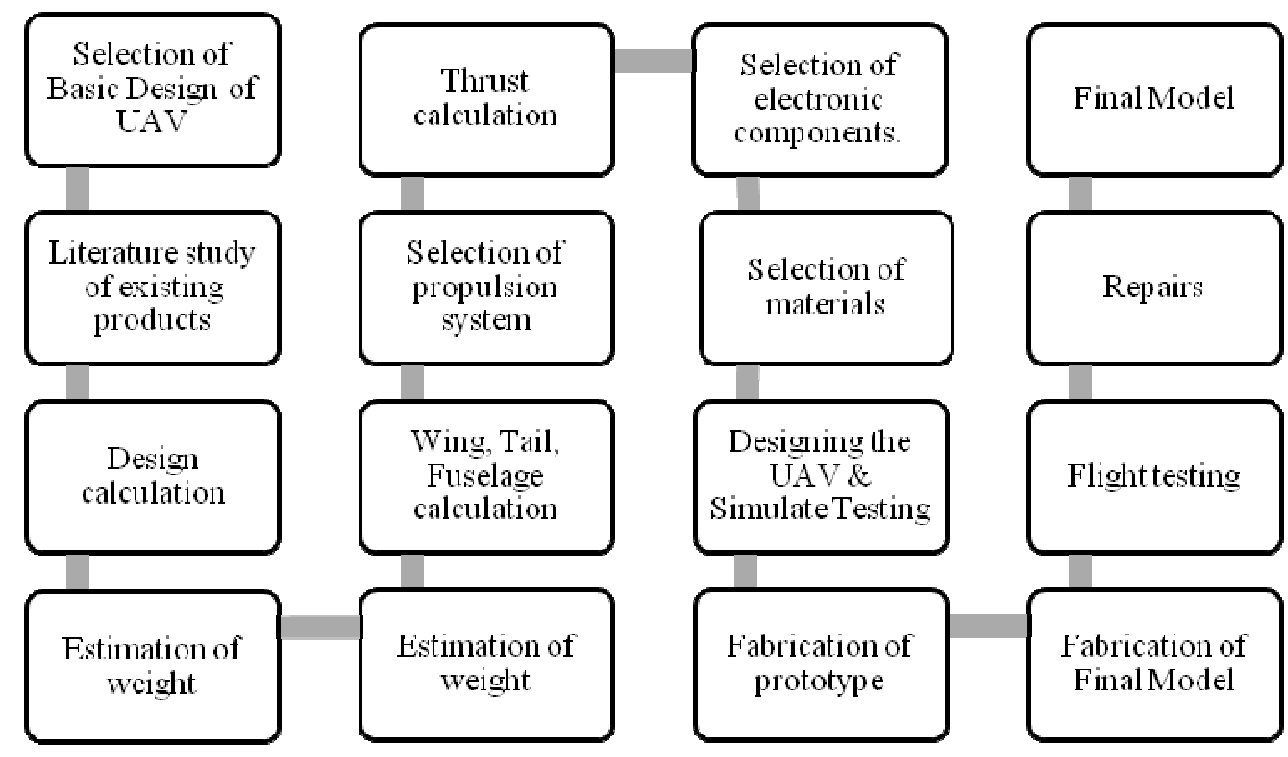

\section{UAV DESIGN CALCULATION AND CAD MODELING}

\subsection{Airfoil Selection}

Airfoil plays a crucial aerodynamic role in generating lift. The airfoil determines the performance characteristics of the designed UAV. The selection of an airfoil for the wings is the primary means to ensure sufficient aerodynamic forces. For 
an aircraft such as this one, the wings must provide high lift at an approximate Reynolds number of 150,000. This Reynolds number was calculated using an assumed aircraft velocity of $45 \mathrm{~km} / \mathrm{h}$, a chord length of .4 m, and historical environmental conditions. The team investigated a few airfoils and found two very promising those are NACA 63-412 and AG35.

The important characteristics of the airfoil are thickness to chord ratio, location of the aerodynamic center, leading-edge radius, etc.

The following graphs:

- $\quad$ CL v/s Alpha

- $\quad \mathrm{CD}$ v/s Alpha

- $\quad \mathrm{CM}$ v/s Alpha

- $\quad$ L/D v/s Alpha

were generated for the selected airfoils and the results were analyzed to finalize the required airfoil.

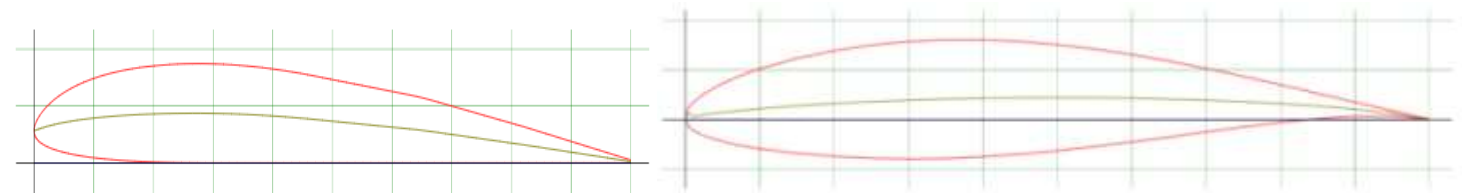

Figure 2

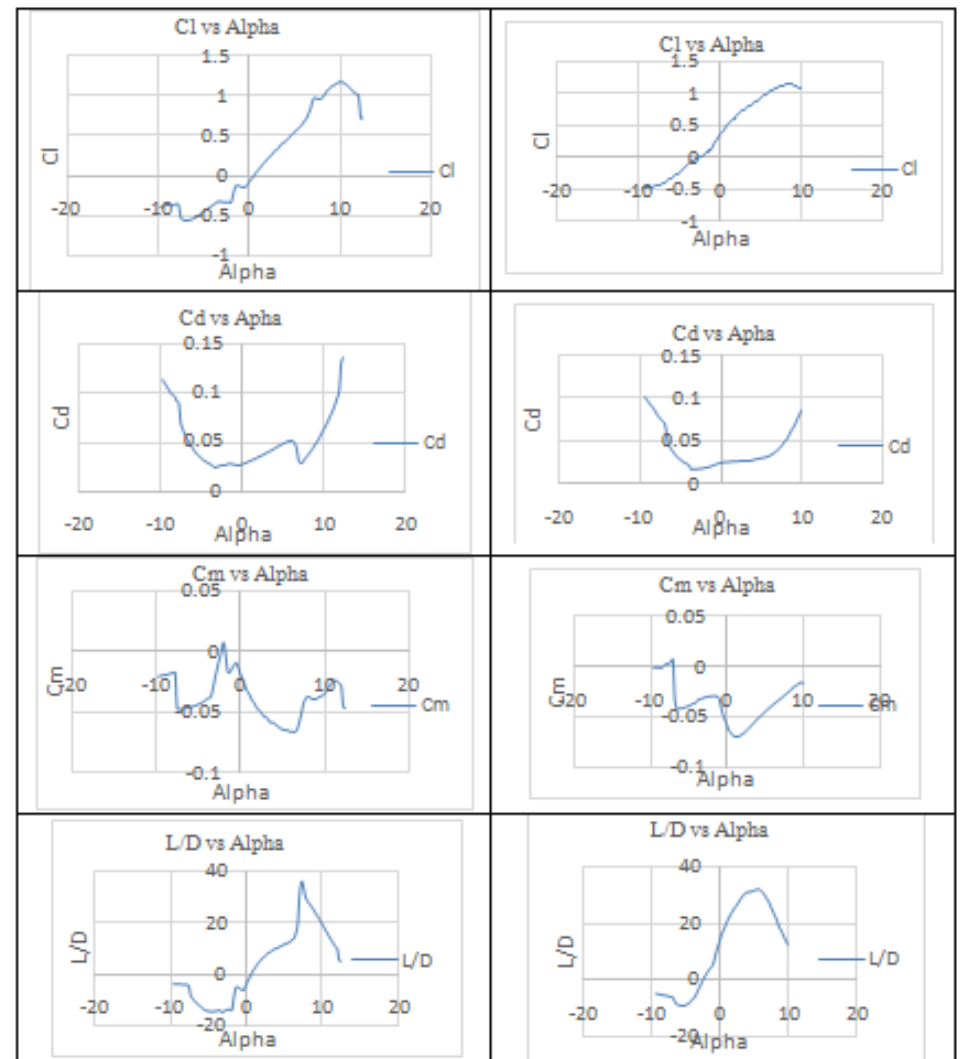

Figure 3: The Graph between the Different Parameter ofNACA 63-412 and AG 13. 


\subsection{Weight Estimation}

The weight of the aircraft is a key factor in most aircraft performance problems. Lowest weight of aircraft design is a subject of utmost importance, although weight minimization is attained at some additional initial cost, it proves beneficial in the long run.

The maximum takeoff weight for an aircraft is the total designed weight when it begins its mission. For any UAV, $\mathrm{W}_{0}=\mathrm{W}_{\mathrm{e}}+\mathrm{W}_{\mathrm{pl}}+\mathrm{W}_{\mathrm{f}}$

Where is the $\mathrm{W}_{\mathrm{e}}$ empty weight, $\mathrm{W}_{\mathrm{pl}}$ is the payload weight, $\mathrm{W}_{\mathrm{f}}$ is the fuel weight.

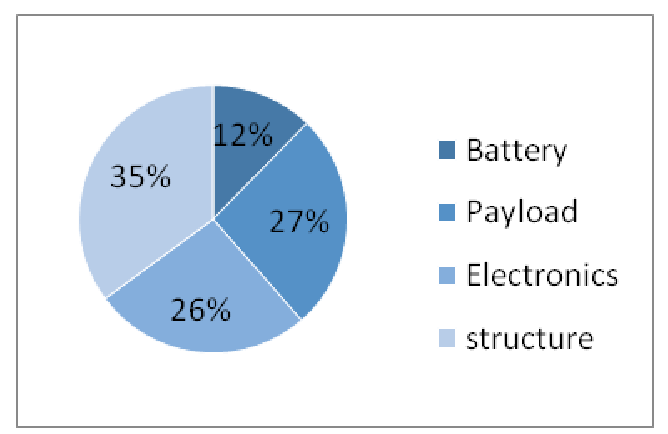

Figure 4: Take-off Weight Estimation.

Table 2: Takeoff Weight Estimation

\begin{tabular}{|c|l|c|}
\hline S No & Particulars & Weight \\
\hline 1 & Battery & $0.7 \mathrm{~kg}$ \\
\hline 2 & Payload & $1 \mathrm{~kg}$ \\
\hline 3 & Structure & $2.4 \mathrm{~kg}$ \\
\hline 4 & Electronics & $0.45 \mathrm{~kg}$ \\
\hline
\end{tabular}

Structure weight is the combined weight of wing, fuselage, and empennage of the UAV. And usually accounts for about $32 \%$ of gross weight.

Table 3: Structure Weight Estimation

\begin{tabular}{|l|l|c|}
\hline S. No & \multicolumn{1}{|c|}{ Particulars } & Weight \\
\hline 1 & Left-Wing & $645 \mathrm{~g}$ \\
\hline 2 & Right Wing & $645 \mathrm{~g}$ \\
\hline 3 & Fuselage + Payload cabin & $455 \mathrm{~g}$ \\
\hline 4 & Vertical tail & $265 \mathrm{~g}$ \\
\hline 5 & Horizontal tail & $190 \mathrm{~g}$ \\
\hline 6 & Boom & $200 \mathrm{~g}$ \\
\hline
\end{tabular}




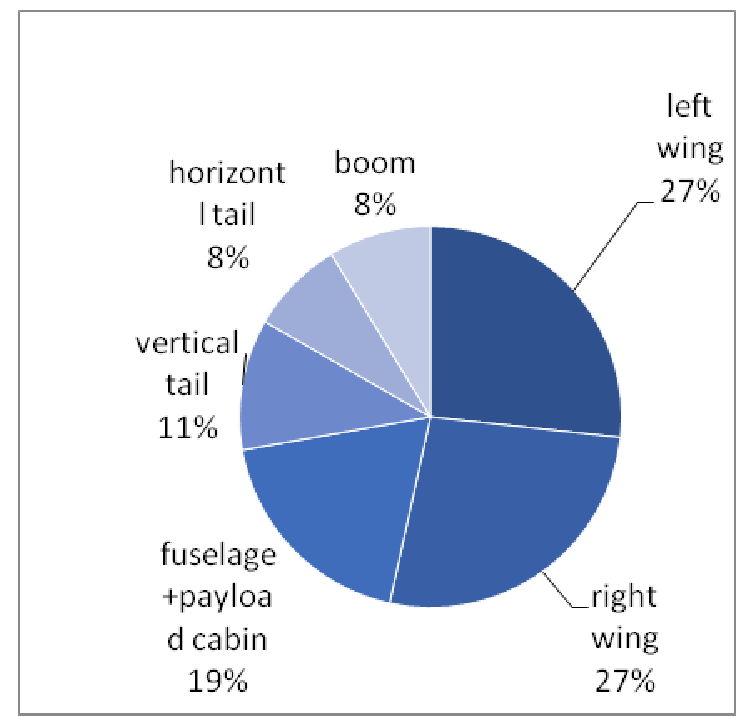

Figure 5: Structure of Weight Estimation.

Electronic components play a major role in the working of a UAV. The combined weight of all the electronic components contributes to the electronic weight.

:

Table 4: Electronics Weight Estimation

\begin{tabular}{|c|l|c|}
\hline S. No & \multicolumn{1}{|c|}{ Particulars } & Weight \\
\hline 1 & Electronic Speed Controller & $90 \mathrm{~g}$ \\
\hline 2 & Ducted fan +Motor & $300 \mathrm{~g}$ \\
\hline 3 & Servo & \\
\hline 4 & Wires & $10 \mathrm{~g}$ \\
\hline 5 & Receiver & $50 \mathrm{~g}$ \\
\hline
\end{tabular}

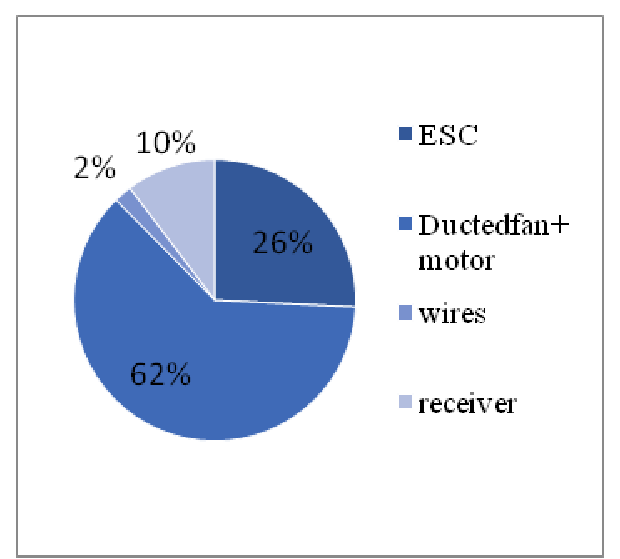

Figure 6: Electronics Weight Estimation.

4.4. Design Calculation and Formula used

Table 5: Design Calculation Formula and Dimension

\begin{tabular}{|c|l|l|c|}
\hline S.No & \multicolumn{1}{|c|}{ Parts } & Dimension \\
\hline 1 & WING & Wing loading (W/s) & $7.386 \mathrm{~kg} / \mathrm{m}^{2}$ \\
\hline & & Wing surfacearea & $0.676 \mathrm{~m}^{2}$ \\
\hline & & Aspect ratio & 7.68 \\
\hline & & Taper ratio & 0.6 \\
\hline
\end{tabular}




\begin{tabular}{|c|c|c|c|}
\hline & & $\begin{array}{l}\text { Wingspan } \\
(\sqrt{ }(\mathbf{A R} \times \mathbf{S}))\end{array}$ & $2.27 \mathrm{~m}$ \\
\hline & & Chord rootlength $(2 \mathrm{~S} /(\mathrm{b} \times(1+\lambda)))$ & $0.40 \mathrm{~m}$ \\
\hline & & Chord tiplength $(\lambda=\mathbf{C t} / \mathbf{C r})$ & $0.24 \mathrm{~m}$ \\
\hline \multirow[t]{6}{*}{2} & HORIZONTALTAI & Surface area (30\% of wingspan) & $0.2028 \mathrm{~m}^{2}$ \\
\hline & & Aspect ratio & 3 \\
\hline & & $\operatorname{Span}(\sqrt{ }(\mathbf{A R} \times \mathbf{S}))$ & $0.8 \mathrm{~m}$ \\
\hline & & Taper ratio & 0.6 \\
\hline & & $\begin{array}{l}\text { Chord rootlength } \\
(2 \mathrm{~S} /(\mathrm{b} \times(\mathbf{1}+\lambda)))\end{array}$ & $0.31 \mathrm{~m}$ \\
\hline & & $\begin{array}{l}\text { Chord tiplength } \\
(\boldsymbol{\lambda}=\mathbf{C t} / \mathbf{C r})\end{array}$ & $0.18 \mathrm{~m}$ \\
\hline \multirow[t]{6}{*}{3} & VERTICAL TAIL & Surface area( $\mathbf{7 0 \%}$ of the horizontal tail surface) & $0.08112 \mathrm{~m}^{2}$ \\
\hline & & Aspect ratio & 2 \\
\hline & & $\operatorname{Span}(\sqrt{(\mathbf{A R} \times \mathbf{S}))}$ & $0.40 \mathrm{~m}$ \\
\hline & & Taper ratio & 0.6 \\
\hline & & $\begin{array}{l}\text { Chord rootlength } \\
(2 \mathrm{~S} /(\mathrm{b} \times(\mathbf{1}+\lambda)))\end{array}$ & $0.27 \mathrm{~m}$ \\
\hline & & $\begin{array}{l}\text { Chord tiplength } \\
(\lambda=\mathbf{C t} / \mathbf{C r})\end{array}$ & $0.16 \mathrm{~m}$ \\
\hline 4 & ELEVATOR & Length (20 \% of horizontal tail) & $0.040 \mathrm{~m}$ \\
\hline 5 & RUDDER & Length (1/8 of a chord) & $0.03125 \mathrm{~m}$ \\
\hline 6 & FUSELAGE & Length (70\% of wingspan) & $1.589 \mathrm{~m}$ \\
\hline
\end{tabular}

\subsection{D Draft View}

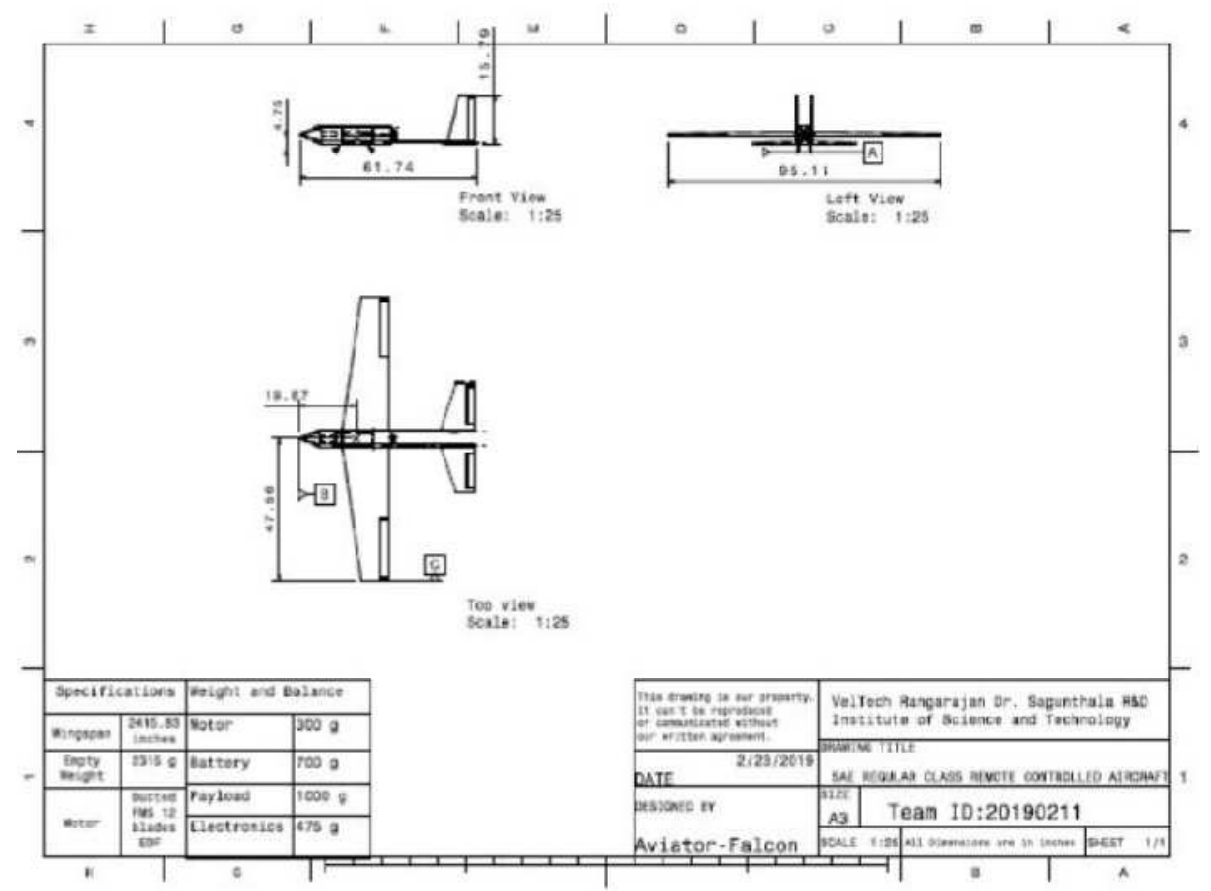

Figure 7: 2D Draft View. 


\subsection{CAD Model}

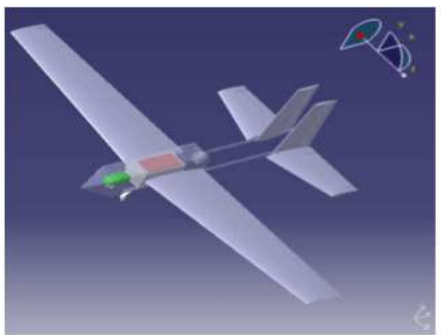

(a)

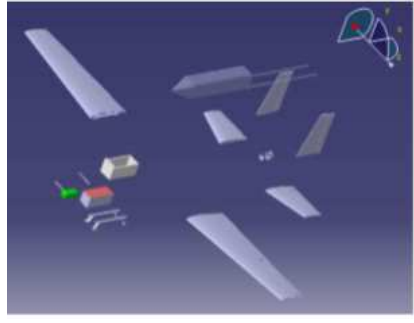

(b)

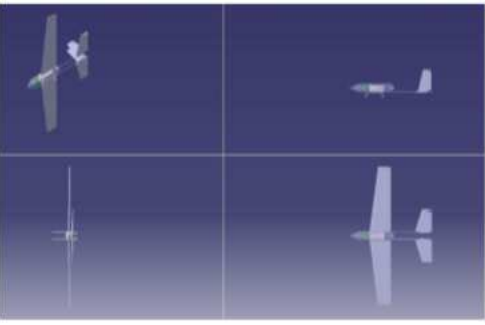

(c)

Figure 8: (a) Assembled View (b) Bombarded View

(c)Various View of Aircraft.

\section{SELECTION OF PROPULSION SYSTEM}

- $\quad$ Weight $=5 \mathrm{~kg}$

- $\quad$ As per the list $\mathrm{T} / \mathrm{W}=0.5-0.7$

- $\quad$ Required thrust $\mathrm{T} / 5=0.5$

- $\mathrm{T}=2.5$ (minimum thrust)

Table 6: Electronics Components Details

\begin{tabular}{|c|c|c|}
\hline $\begin{array}{c}\text { S. } \\
\text { No }\end{array}$ & Components & Specification \\
\hline 1 & $\begin{array}{l}\text { Motor: Motor: DUCTED FMS 80mm } 12 \text { Blades Ducted } \\
\text { Fan EDF with } 3270 \text { KV2000 6S in runner Brushless Motor }\end{array}$ & $\begin{array}{ll}\text { - } & \text { Item Name: } 80 \mathrm{~mm} 12 \text { blades Ducted Fan } \\
\text { - } & \text { Motor: } 3270 \mathrm{KV} 2000 \\
\text { - } & \text { Weight: } 300 \mathrm{~g} \\
\text { - } & \text { Battery: } 6 \mathrm{~S} 4000 \mathrm{mAh} 45 \mathrm{C} \text { lipo } \\
\text { - } & \text { ESC: } 100 \mathrm{~A} \text { brushless } \\
& \text { Maximum thrust }-3200 \mathrm{~g}\end{array}$ \\
\hline 2 & $\begin{array}{l}\text { ESC: Fly color V1.3-win dragon WIFI 100A 2-6S Lipo } \\
\text { Brushless ESC for RC Airplane Aircraft }\end{array}$ & $\begin{array}{ll}\text { - } & \text { Continuous current: } 100 \mathrm{~A} \\
\text { - } & \text { Instantaneous current }(10 \mathrm{~s}): 120 \mathrm{~A} \\
\text { - } & \text { BEC: } 8.4 \mathrm{~V} / 7.4 \mathrm{~V} / 6 \mathrm{~V} / 5 \mathrm{~V}, 3 \mathrm{~A} \\
\text { - } & \text { Support voltage: } 2-6 \mathrm{~S} \\
\text { - } & \text { Weight: } 125 \mathrm{~g} \\
\text { - } & \text { Size: } 82.5 \times 39.5 \times 23.5 \mathrm{~mm}\end{array}$ \\
\hline 3 & $\begin{array}{l}\text { Battery: ORANGE } 16000 \text { mah } 6 \mathrm{~S} 25 \mathrm{C} / 50 \mathrm{C} \text { lithium polymer } \\
\text { battery pack (lipo) } \\
\text { Orange }\end{array}$ & $\begin{array}{ll}\text { - } & \text { Model No: ORANGE } 16000 \text { / 6S-25/50C } \\
\text { - } & \text { Capacity: } 16000 \mathrm{MAh} . \\
\text { - } & \text { Weight: } 1900 \mathrm{gm} . \\
\text { - } & \text { Voltage: } 22.2 \mathrm{~V} .\end{array}$ \\
\hline
\end{tabular}




\begin{tabular}{|l|l|l|l|}
\hline & Servo: Power HD AR-1201MG Servo 12 to $13 \mathrm{KG}$ Torque & $\begin{array}{l}\text { This is a powerful metal gear servo with } \\
\text { torque ranging between } 12 \text { to } 13 \mathrm{KG} .\end{array}$ \\
$\begin{array}{l}\text { This servo runs on } 4.8 \mathrm{~V} \text { and } 6 \mathrm{~V} \text { and } \\
\text { strictly not more than } 6 \mathrm{~V} .\end{array}$ \\
$\begin{array}{l}\text { Weight is } 60 \mathrm{~g} \\
\text { This servo gives a full } 180 \text {-degree } \\
\text { rotation. }\end{array}$
\end{tabular}

\section{Calculation}

- $\quad$ ESC Rating ESC rating= $[1.2 \text { to } 1.5]^{*}(\max$. ampere rating of the motor $)$

- $\quad \mathrm{RPM} \mathrm{Rpm}=\mathrm{KV}$ rating X Battery Volt input

- $\quad$ Flight Time Capacity in amperes/Current draw) *60

\section{ANALYSIS}

\subsection{Airfoil Analysis}

The performance of the airfoils was analyzed using XFLR

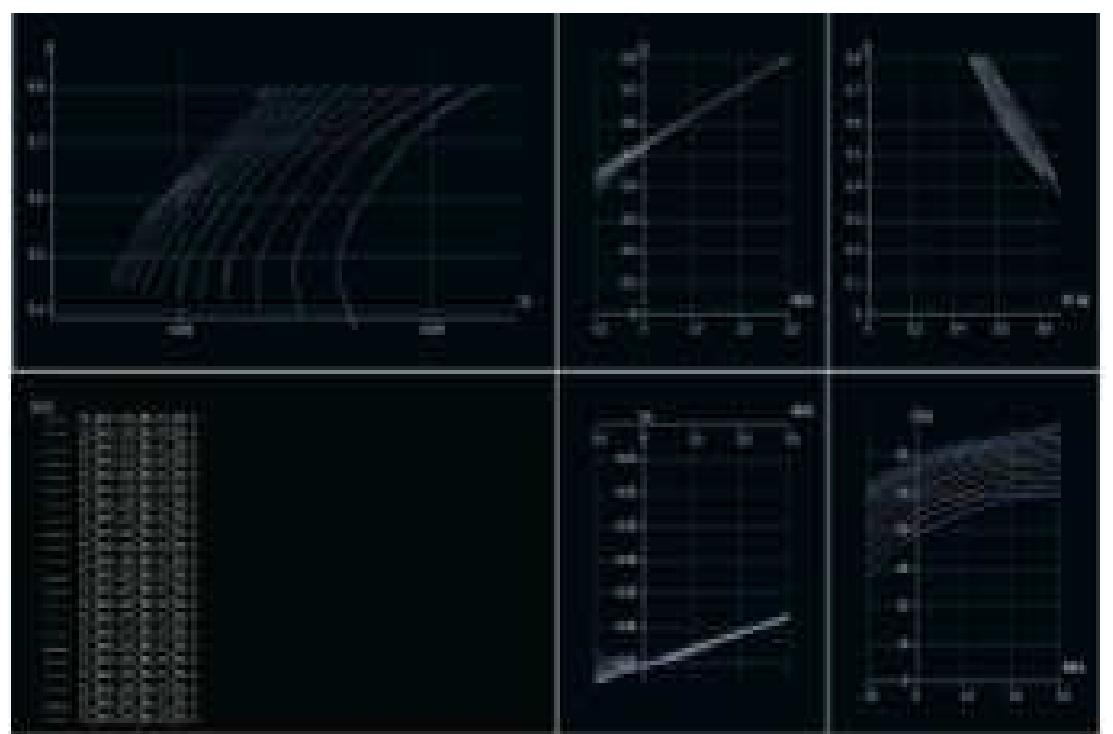

Figure 9: Performance Analysis of Airfoil using XFLR.

The figure depicts the following graphs

- $\quad$ Cl vs. Cd

- $\quad$ Cl vs. Alpha

- $\quad$ Cl vs. Xtr top

- Cm vs. Alpha

- $\mathrm{Cl} / \mathrm{Cd}$ vs. Alpha

\subsection{Structural Analysis}


Structural analysis was done for optimizing landing gear design.

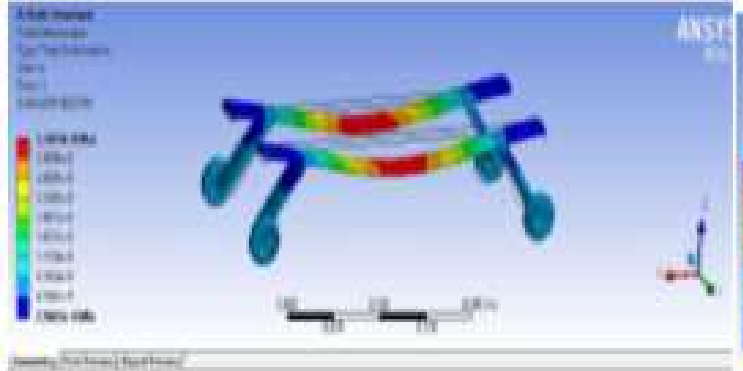

(a)

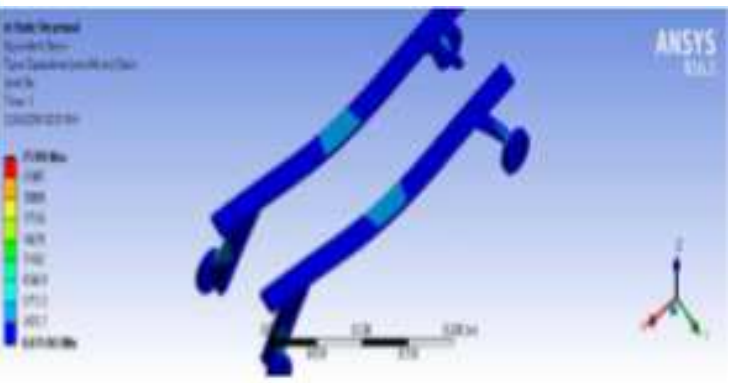

(b)

Figure 10: (a),(b) Structural Analysis for Optimizing Landing Gear Design.

\section{FABRICATION}

\subsection{Smart Locking System for Wings}

For the smart locking system, we have chosen an umbrella's locking mechanism that will hold and lock both the wings with fuselage acting as a secure lock instead of a screw lock or rubber band locking system (usually employed in gliders and small UAVs). In this system, we have used two umbrella locking system: both the locks connected to each wing. As seen in the figure below, the main airfoil-shaped block is fixed in the fuselage. Inside these blocks, holes are drilled and the locking system is placed. The rod-like structure similar to an umbrella runs through the length of the wing, and it snugly fits in the main block where it's latched with the help of the locking system. This system makes it easy to manufacture and also to assemble the model.

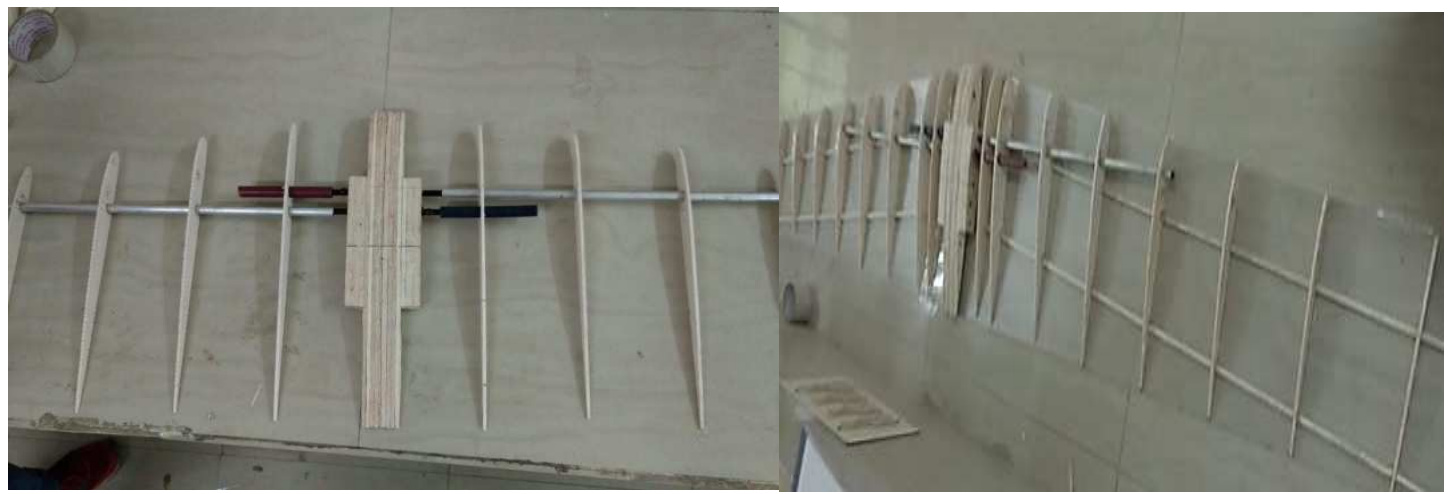

(a)

(b)

Figure 11: (a) Wing Locking Mechanism, (b) Wing Fabrication.

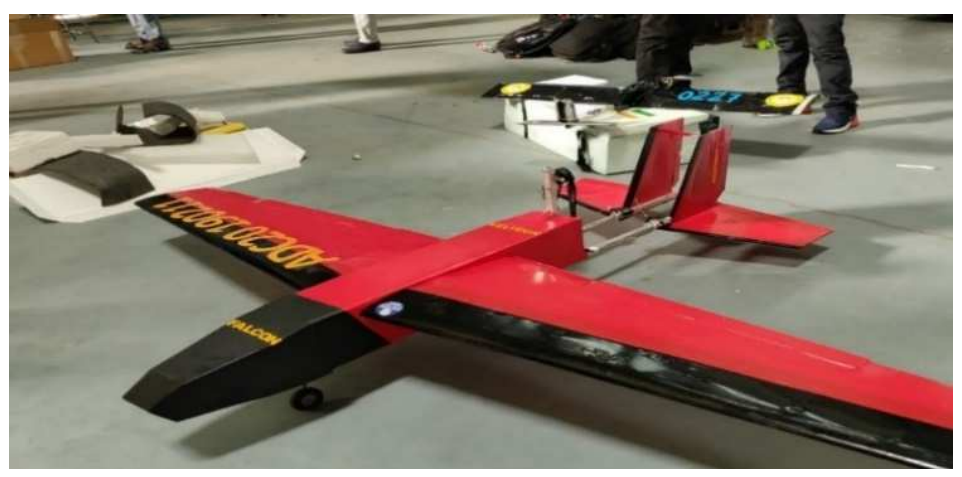

Figure 12: A Finalized Model of UAV 


\section{CONCLUSIONS}

The conceptualized design and analysis of a smart lock system based on regular class Remote Controlled Aircraft is done and the various design considerations and performance parameters required are calculated and found out. The obtained design values are not necessarily a definite reflection of the airplane's true and conceptualized design as little variations are expected while manufacturing, but the basic outlay of development has been obtained. Assumptions in some calculations were made after considering all the related aspects and references required for that. There is no ideal design as such as continuous changes, improvements and innovations serve to make the design as ideal as possible, while always looking to achieve optimum performance and payload carrying capacity. The challenges we faced at various phases of the project made us realize that the experience plays a vital role in the successful design of any aircraft or aircraft component. A lot of effort has been put into this product and as much as we have worked, we have learned in turn.

\section{REFERENCES}

1. Daniel Raymer (1989). Aircraft Design

2. https://www.airforce-technology.com/projects/dvf-2000-shortrange-mini-uav/

3. Undavalli Vivek Chowdary, Kanduru Rohith, Pabolu Sandeep \& Mutyala Ramu, "Home Automation System Using IR Senso “, International Journal of Electrical andElectronics Engineering (IJEEE), Vol. 4, Issue 6, pp. 11-16

4. http://www.sparkletech.hk/\%E9\%B9\%B0\%E7\%9C\%BC\%E6\%97\%A0\%E4\%BA\%BA\%E6\%C\%BA/electricpower $1 \%$ E9\%B9\%B0\%E7\%9C\%BC-4\%E7\%B1\%B3-t-\%E5\%B0\%

5. Tanuja P. Mote, Meenal. R. Majge \& Gouri. P. Brahmankar, "Mechatronics in Automobiles “, International Journal of Electrical and Electronics Engineering (IJEEE), Vol. 5, Issue 5, pp. 13-24

6. https://www.fpvmodel.com/new-mini-mugin-2-6m-uav-t-tail-v-tail-platform-carbon-fiber-tail

7. https://www.aliexpress.com/item/New-Mugin-Plus-4500mm-Plane-New-

ArrivalFPVLareFlying WingElectricGasRCAirplaneLatest/32846648018.html?spm=2114.10010108.1000013.8.2a8721d0keB6 yf\&gpsid=pcDetailBottomMoreThisSeller\&scm=1007.13339.90158.0\&scm_id=107.13339.90158.0\&scmurl $=1007.13339 .90158 .0 \&$ pvid $=8900 a 75 f-2 c 49-4372-a 138$ f16afb7e 2798

8. $\quad$ D Dinesh Kumar, Gella Ajay Kumar \& Movva Srikanth," Monitoring and Controlling of Temperature Using CAN Architecture “, BEST: International Journal of Management, Information Technology and Engineering (BEST: IJMITE), Vol. 2, Issue 6, pp. 61-68

9. https://openuav.eava.eelabout.html

10. Shorunke Muyiwa Musaddiq," Towards Securing Data in the Cloud “, IMPACT: International Journal of Research in Applied, Natural and Social Sciences (IMPACT: IJRANSS), Vol. 2, Issue 4, pp. 123-126

11. http://www.uavfactory.com/download/131/Penguin B Datasheet v2 2.pdf 

